The Chittagong Univ. J. B. Sci., Vol. 5(1 \&2):91-103, 2010.

\title{
EFFICIENT PLANT REGENERATION FROM EMBRYOGENIC CELL SUSPENSION CULTURE OF TWO DEEPWATER RICE (ORYZA SATIVA L.) VARIETIES
}

\author{
L. KHALEDA AND M. AL-FORKAN * \\ Department of Genetic Engineering and Biotechnology, University of Chittagong-4331, \\ Bangladesh.
}

\begin{abstract}
Cell suspension cultures were initiated from 28-30 d old scutellar-derived embryogenic calli of two deepwater rice varieties HAJA-1 and HAJA-8 and maintained on R2 liquid medium containing $2 \mathrm{mg} \mathrm{l}^{-1} 2,4-\mathrm{D}$. The formation of fine embryogenic cell suspensions and subsequent plant regeneration were dependent on plant genotype and culture media. Variety HAJA-8 was found less viable than the other variety HAJA-1. In general, it was observed that variety HAJA-1 showed better performance compared to variety HAJA-8 to R2 medium for the initiation of embryogenic cell lines and the rate of the cell growth was higher in this variety. Plant regeneration was not obtained from cell suspensions of both varieties when cells were cultured on regeneration media semi-solidified with $0.4 \%(\mathrm{w} / \mathrm{v})$ agarose. Plant regeneration from cell suspensions of the both varieties were obtained when the agrose concentration of the regeneration media was increased from 0.4 to $1 \%(\mathrm{w} / \mathrm{v})$. The highest plant regeneration frequencies were obtained from cell suspensions of the varieties HAJA-1 and HAJA-8 (48\%) and (42\%), respectively, pre-treated with water for $5 \mathrm{~h}$ and cultured on MS medium supplemented with $2 \mathrm{mg} \mathrm{l}^{-1} \mathrm{BAP}+1 \mathrm{mg} \mathrm{l}^{-1}$ Proline. Washing cell suspensions with water for a prolonged period of time ( $15 \mathrm{~h}$ and more) inhibited plant regeneration.
\end{abstract}

Key words: Deepwater rice, cell suspension, plant regeneration, embryogenesis.

\section{INTRODUCTION}

As the population expands there has been increasing concern over whether current rates of food productions can support the growing populations. In response to the increasing demand, scientists and farmers have been working hard to come up with new ideas to meet these needs. Cell suspension cultures of rice can be initiated using a wide range of explants including root, anthers, leaf bases,

* Corresponding author : E-mail: alforkancu@hotmail.com 
immature panicles and immature or mature embryos (Abe and Futsuhara 1991). However, many agronomically valuable genotypes are recalcitrant to in vitro manipulation because of their poor regeneration ability. These rates could increase if appropriate improvement were made to the tissue culture medium (Zhu et al. 1996). This article focuses on one of the important aspects of plant science, which is the growth of plant cells in an artificial medium. Cell culture techniques are necessary for the use of biotechnology including the production of transgenic rice plants.

Embryogenic cell suspension cultures are used routinely as source materials for the enzymatic isolation of totipotent protoplasts, which have been exploited in plant genetic manipulation studies (Blackhall et al. 1999, Al-Forkan et al. 2001). It is strongly depended on plant genotype, physiological stages of explants, the composition of culture medium and conditions of culture. Lee et al. (2004) and Tang et al. (2001) focused on developing suspension cell culture while Wenging et al. (1997) shows potential of suspension after 14 months culture, but none of plant regeneration from fresh callus derived from mature seeds.

Direct plant regeneration has been reported for cell suspension cultures initiated from Japonica rice (Tsukahara et al. 1996). Ozawa and Komamine (1989) reported that the plant regeneration frequency (48\%) from suspension cultures of Indica rice cv. Konansou cultured in liquid medium was lower than that on semi-solid medium (93\%). Plant regeneration has been described via somatic embryogenesis, for long-term (15 month-old) cell suspension cultures of the Indica rice cv. IR43 (Ghosh Biswas and Zapata 1992). Jain et al. (1996) reported that the frequency of plant regeneration from cell suspensions was significantly increased using water stress treatments in two commercially important Indica rice cvs. Basmati 385 and Pusa Basmati 1. The present study was undertaken with a view to developing an efficient plant regeneration protocol from cell suspension cultures of deepwater rice.

\section{MATERIALS AND METHODS}

\section{Plant materials and media}

Seeds of two deepwater rice varieties HAJA-1 and HAJA-8 collected from the Regional Station, Habiganj of Bangladesh Rice Research Institute, were used to initiate callus cultures on MS medium (Murashige and Skoog 1962) and cell suspension culture on R2 (Ohira et al. 1973) liquid medium. 


\section{PLANT REGENERATION FROM EMBRYOGENIC CELL SUSPENSION CULTURE OF RICE}

\section{Initiation and maintenance of cell suspension culture}

Cell suspension cultures were initiated from 28-30d scutellar-derived embryogenic calli. At first, embryogenic calli portions were transferred to $25 \mathrm{ml}$ flasks each containing $7 \mathrm{ml}$ of liquid R2 medium. Four cell suspension lines of discrete calli were initiated for each variety. Then cultures were incubated on shaker at $60 \mathrm{rpm}$ at $26 \pm 2^{\circ} \mathrm{C}$ in the dark. During the first stage of initiation, $6 \mathrm{ml}$ culture medium was replaced at the day 3 and every 3-day. After 4 weeks culture were transferred by pouring into $100 \mathrm{ml}$ flask and replacing all the (spent medium) culture with $22 \mathrm{ml}$ of fresh R2 medium. After 2 weeks, suspensions were sub-cultured every $7 \mathrm{~d}$ by the transfer of $1 \mathrm{ml} \mathrm{PCV}$ with $7 \mathrm{ml}$ spent medium to $22 \mathrm{ml}$ fresh R2 medium. After $60 \mathrm{~d}, 2 \mathrm{ml} \mathrm{PCV}$ of suspension culture with $10 \mathrm{ml}$ of spent medium were transferred to $250 \mathrm{ml}$ flasks containing $40 \mathrm{ml} \mathrm{R} 2$ medium. The cell suspensions were routinely sub-cultured on every $7 \mathrm{~d}$.

\section{Estimation of growth rate of cell suspension culture}

Established cell suspension culture ( $2 \mathrm{ml}$ PCV) with $10 \mathrm{ml}$ of spent medium and $40 \mathrm{ml}$ fresh medium were transferred to $250 \mathrm{ml}$ flasks. These flasks were incubated under growth conditions as described earlier but without subculturing from day 0 and daily, $10 \mathrm{ml}$ of cell suspension was taken out by pipette and left for settling down and measured Packed Cell Volume (PCV) over an assessment period of 0-16 d. Data were collected from 3 flasks per variety with five reading taken per flasks.

\section{Plant regeneration from cell suspension culture}

Cell suspensions of variety HAJA-1 and HAJA-8 initiated in R2 medium, were evaluated for plant regeneration potential on several regeneration media (Table 1) whereby plant growth regulators (PGRs), choice of plant growth regulators, agarose concentration (Assessment 1 and 2) and pre-treatment with water (Assessment 3) on plant regeneration were investigated. Three-month-old cell suspensions of varieties HAJA-1 and HAJA-8 were used for these experiments. After $4 \mathrm{~d}$ sub-cultured, approximately $1 \mathrm{~g}$. fresh weight of cells was subjected to the following different experiments. 
KHALEDA AND AL-FORKAN

TABLE 1: MS-BASED MEDIA USED FOR PLANT REGENERATION ASSESSMENTS FORM CELL SUSPENSION-DERIVED CALLI OF VARIETIES HAJA-1 AND HAJA-8.

\begin{tabular}{ccccccc}
\hline \multirow{2}{*}{$\begin{array}{c}\text { Media } \\
\text { code }\end{array}$} & \multicolumn{5}{c}{ Plant growth regulators $\left(\mathrm{mg} \mathrm{l}^{-1}\right)$} & \multicolumn{3}{c}{$\begin{array}{c}\text { Sucrose conc. } \\
{[\%(\mathrm{w} / \mathrm{v})]}\end{array}$} \\
\cline { 2 - 7 } & BAP & Kinetin & NAA & Proline & ABA \\
\hline MSBN & 2 & - & 0.5 & - & - & 3 \\
MSB & 2 & - & - & - & - & 3 \\
MSKN & - & 2 & 0.5 & - & - & 3 \\
MSK & - & 2 & - & - & - & 3 \\
MSBA & 2 & - & - & - & 5 & 3 \\
MSBP & 2 & - & - & 1 & - & 3 \\
MSKA & - & 3 & - & - & 5 & 3 \\
\hline
\end{tabular}

Regeneration from callus derived from cell suspension: Assessment 1: Plant growth regulators

Cell suspensions were initially transferred, after removing the liquid medium (R2) with a $10 \mathrm{ml}$ sterile pipette, into $9 \mathrm{~cm}$ petri dishes containing $20 \mathrm{ml}$ of semi-solidified MS medium supplemented with $2 \mathrm{mg} \mathrm{l}^{-1}$ 2,4-D. Dishes were incubated in the dark at $28 \pm 1^{\circ} \mathrm{C}$ for 14 day. During this period, cell colonies proliferated rapidly. Actively growing calli were selected from the proliferating colonies and transferred to the regeneration media (Table 1) (20 calli per/dish, 5 replica/treatment) semi-solidified with $0.4 \%$ (w/v) agarose, cultures were kept in the dark for $10 \mathrm{~d}$ before transfer to light. The regeneration potential of the calli were evaluated using a range of regeneration media (Table 1).

Regeneration directly from cell suspension cultures: Assessment 2: Agarose concentration

In this assessment, the effects of the agarose concentration on the plant regeneration were evaluated. Cell suspensions, initiated in R2 medium, were directly transferred for 10 day to regeneration media (Table 1) semi-solidified with $0.4 \%$ or $1 \%(\mathrm{w} / \mathrm{v})$ agarose. Cultured were maintained as described in assessment 1 . 


\section{PLANT REGENERATION FROM EMBRYOGENIC CELL SUSPENSION CULTURE OF RICE}

Regeneration directly from cell suspension cultures: Assessment 3: Water pretreatment

Effect of pre-water treatment was evaluated to investigate any beneficial effects on plant regeneration efficiency, since the later was found to be very low from cell suspension initiated in R2 medium. Cell suspensions of varieties HAJA-1 and HAJA-8 initiated in R2 medium were directly transferred to $100 \mathrm{ml}$ flasks containing $15 \mathrm{ml}$ of sterile reverse-osmosis water. Cultures were incubated on a rotary shaker at $28 \pm 1^{\circ} \mathrm{C}$ in the dark and cells were collected, after $1 \mathrm{~h}, 5 \mathrm{~h}, 10 \mathrm{~h}$ or $20 \mathrm{~h}$ of pre-water treatment, and dried on two sterile, superimposed $7 \mathrm{~cm}$ diameter. dry filter paper disks for $15 \mathrm{~min}$, before transfer onto regeneration medium (Table 1) semi-solidified with $1 \%$ (w/v) agarose. Cultures were maintained as described in assessment 1.

\section{Rooting of plants}

Plant regenerated from (Assessments 1, 2 and 3) cell suspensionderived calli were transferred onto LS (Linsmaier and Skoog 1965) based rooting medium, which consist of LS $+2 \mathrm{mg}^{-1} \mathrm{BAP}+1.5 \mathrm{mg} \mathrm{l}^{-1} \mathrm{NAA}$. Regenerated plants (20 plants/treatment), each approximately $5-6 \mathrm{~cm}$ in height were transferred to pot for hardening and establishment.

\section{RESULTS AND DISCUSSION}

\section{Initiation and establishment of cell suspension culture}

After 5 weeks of medium replacement, suspension cultures of both varieties were initiated from embryogenic calli (Fig. 2A) in R2 media were composed of two types of cell groups, for example, actively dividing densely cytoplasmic cells, elongated and vacuolated cells. At this period, selective subculture of rapidly growing suspensions was performed. Such suspensions consisted of highly cytoplasmic groups of cells, which were rapidly dividing and gradually increased with time (Fig. 2B). It was necessary to keep the cultures in the exponential growth phase to maintain an embryogenic cell suspension culture. A $7 \mathrm{~d}$ subculture interval found to be optimal to maintain embryogenic cell suspension cultures.

Effect on genotype on the initiation and establishment of embryogenic cell suspension cultures

Cell growth, measures by an increase in fresh weight (g/flask) displayed a growth curve with exponential, a small decline in growth $(9 \mathrm{~d})$ and finally, death 
phase start on day 12. Cell growth increasing continued for up to 1-7 d for variety HAJA-1 and 1-8 for variety HAJA-8 (Fig.1). It was also observed that variety HAJA-1 showed better performance compare to variety HAJA-8 in R2 medium for the initiation of embryogenic cell suspension culture. Moreover, the rate of the cell growth was higher in this variety.

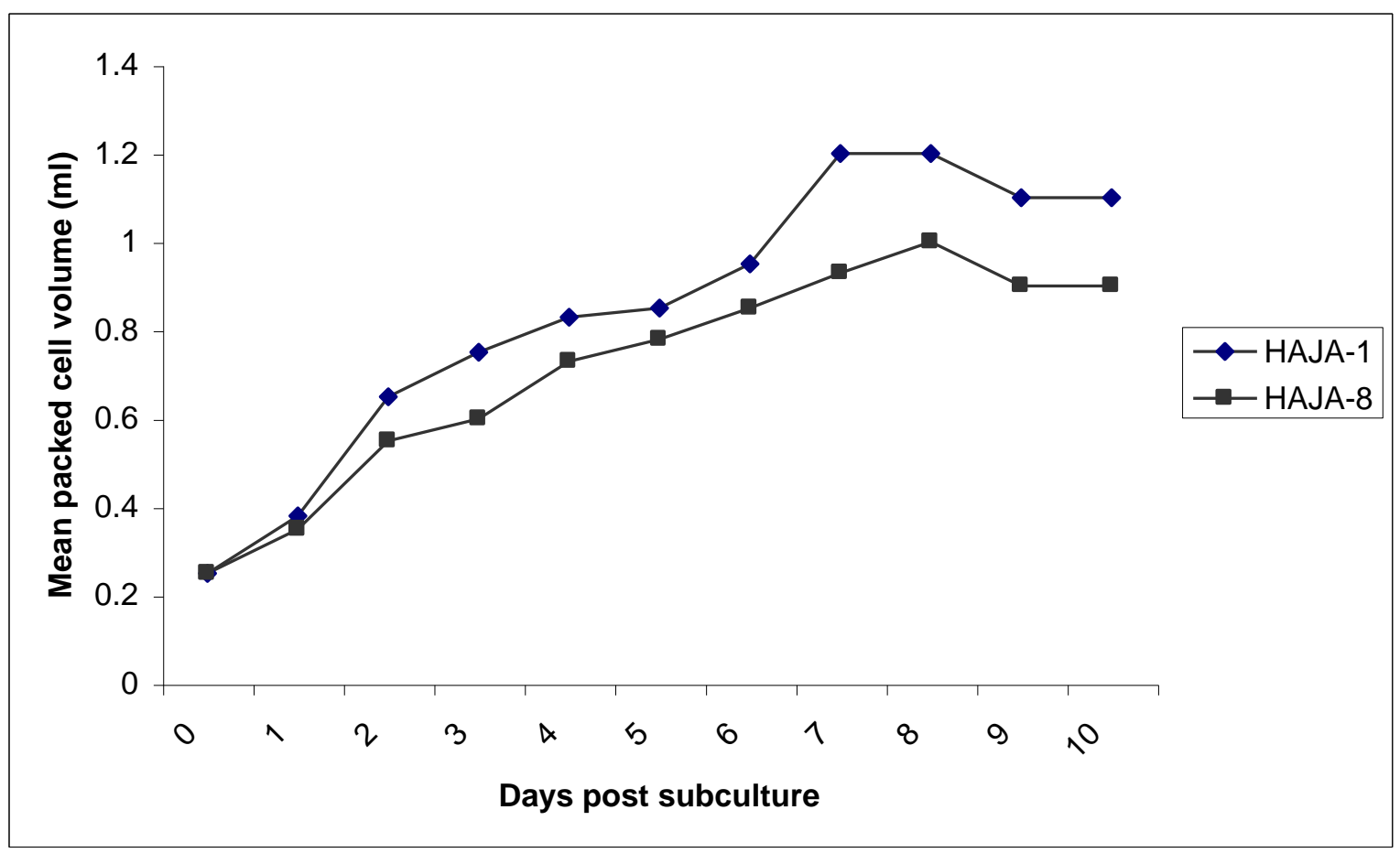

FIGURE 1: GROWTH CURVES OF CELL SUSPENSION CULTURES OF VARIETIES HAJA1 AND HAJA-8 IN R2 MEDIUM.

Plant regeneration from cell suspension

Regeneration of callus derived from cell suspension: Assessment 1: Plant growth regulators

Cell suspension derived calli transferred from semi-solidified MS medium to regeneration media resulted in greening of the callus after 5-7 $\mathrm{d}$ of culture in the light on all regeneration media (Table 2, Fig. 2C).Variety HAJA-1 cells initiated in R2 medium and transferred to regeneration media (Table 2) and produced the highest percentage $(18 \%)$ of plant on MSBP medium compare to all the other media tested. On the same regeneration medium, variety HAJA-8 


\section{PLANT REGENERATION FROM EMBRYOGENIC CELL SUSPENSION CULTURE OF RICE}

produced comparatively lower percentage of $(12 \%)$ plant while only kinetin supplemented medium MSK responded poorly in both the varieties.

TABLE 2: PLANT REGENERATION FROM INDIVIDUAL CELL-SUSPENTION-DERIVED CALLI.

\begin{tabular}{ccc}
\hline \multirow{2}{*}{ Media Code } & \multicolumn{2}{c}{ \% of plant regeneration } \\
\cline { 2 - 3 } & Var. HAJA-1 & Var. HAJA-8 \\
\hline MSBN & 8.01 & 6.03 \\
MSB & 11.03 & 9.01 \\
MSKN & 4.03 & 3.01 \\
MSK & 2.01 & 1.02 \\
MSBP & 18.06 & 12.04 \\
\hline
\end{tabular}

Regeneration directly from cell suspension cultures: Assessment 2: Agarose concentration

There was no plant regeneration from cell suspensions of both the varieties when cells were cultured on regeneration media semi-solidified with $0.4 \%(\mathrm{w} / \mathrm{v})$ agarose. However, plant regeneration from cell suspensions of both varieties were obtained when the agarose concentration of the regeneration media was increased from $0.4 \%$ to $1 \%(\mathrm{w} / \mathrm{v})$. Wide range of differences in the regeneration frequencies of the different media were observed (Table 3 ).

MSKN, MSK and MSBP media responded better than the rest of the media assessed (Table 3) for promoting plant regeneration, but there is no significant difference with respect to regeneration frequencies among these three media (Table 3). The highest plant regeneration frequency was obtained on MSKN $(52 \%)$ in variety HAJA-1, while variety HAJA-8 produced $43 \%$ of the plant on the same medium. MS medium supplemented with $2 \mathrm{mg} \mathrm{l}^{-1} \mathrm{BAP}+1 \mathrm{mg}^{-1}$ Proline (MSBP) promoted plant regeneration comparatively better than all others media tested (Table 3). 
KHALEDA AND AL-FORKAN

TABLE 3: EFFECT OF 1\% AGAROSE ON PLANT REGENERATION FROM CELL SUSPENSION-DERIVED CALLI.

\begin{tabular}{ccc}
\hline \multirow{2}{*}{ Media Code } & \multicolumn{2}{c}{ \% of plant regeneration } \\
\cline { 2 - 3 } & Var. HAJA-1 & Var. HAJA-8 \\
\hline MSBN & 10.03 & 7.03 \\
MSKN & 52.03 & 43.01 \\
MSK & 50.01 & 45.03 \\
MSBP & 47.06 & 45.04 \\
MSBA & 20.08 & 13.01 \\
MSKA & 12.02 & 8.07 \\
\hline
\end{tabular}

Regeneration directly from cell suspension cultures: Assessment 3: water pretreatment

Since moderate regeneration frequencies were obtained from cell suspensions derived calli of either HAJA-1 or HAJA-8 medium (Table 2 and 3), an assessment was carried out to examine the effects of pre-treatment with water on plant regeneration efficiency. The highest plant regeneration frequencies were obtained from cell suspensions of the varieties HAJA-1 (48\%) and HAJA-8 (42\%), pre-treated with water for $5 \mathrm{~h}$ and cultured on MSBP regeneration medium (Table 4, Fig. 2C). In the case of HAJA-1 and for cell suspensions pre-treated with water for $5 \mathrm{~h}$, MSBP medium was comparatively better in terms of plant regeneration frequency than pre-treated with water for 1 and $10 \mathrm{~h}$ and cultured in all other media assessed (Table 4). Cell suspensions of HAJA-8 did not produce plants when cells were pre-treated with water for $20 \mathrm{~h}$ and cultured on regeneration media, except in the case of MSBP medium (Table 4). In case of variety HAJA-1, wide range of variations were found in plant regeneration frequencies among the durations of pre-treatment with water $(1 \mathrm{~h}, 5 \mathrm{~h}, 10 \mathrm{~h}$ and $20 \mathrm{~h}$ ) prior to transfer to regeneration media (Table 4).

Interestingly, pre-treatment with water for $5 \mathrm{~h}$ and cultured in MSBP medium was also found to be the best in promoting the highest frequency of plant regeneration. Similarly, plant regeneration did not occur from HAJA-8 cell suspensions cultured, after $10 \mathrm{~h}$ pre-treatment with water, on any of those 
regeneration media including MSBP (Table-4). Plants (4-5 cm in height) regenerated (Assessment 1, 2 and 3) from cell suspension-derived calli of variety HAJA-1 and HAJA-8 were transferred to rooting media for 10 days. All such plants were successfully rooted (Fig. 2D).

TABLE 4: EFFECT OF PRE-TREATMENT WITH WATER ON PLANT REGENERATION FROM CELL SUSPENSION-DERIVED CALLI.

\begin{tabular}{lcccccccc}
\hline $\begin{array}{c}\text { Medium } \\
\text { code }\end{array}$ & \multicolumn{7}{c}{ \% of plant } & \multicolumn{7}{c}{ regeneration } \\
\cline { 2 - 9 } & \multicolumn{9}{c}{ Var. HAJA-1 } & \multicolumn{5}{c}{ Var. HAJA-8 } \\
\cline { 2 - 9 } & $1 \mathrm{~h}$ & $5 \mathrm{~h}$ & $10 \mathrm{~h}$ & $20 \mathrm{~h}$ & $1 \mathrm{~h}$ & $5 \mathrm{~h}$ & $10 \mathrm{~h}$ & $20 \mathrm{~h}$ \\
\hline MSBN & 16.02 & 29.05 & 14.03 & 0.00 & 15.05 & 21.06 & 9.03 & 0.00 \\
MSKN & 14.02 & 38.05 & 10.01 & 0.00 & 12.02 & 37.02 & 8.02 & 0.00 \\
MSK & 16.03 & 35.02 & 16.03 & 0.00 & 17.04 & 37.02 & 4.01 & 0.00 \\
MSBP & 20.01 & 48.03 & 17.02 & 13.01 & 16.03 & 42.02 & 13.04 & 0.00 \\
\hline
\end{tabular}
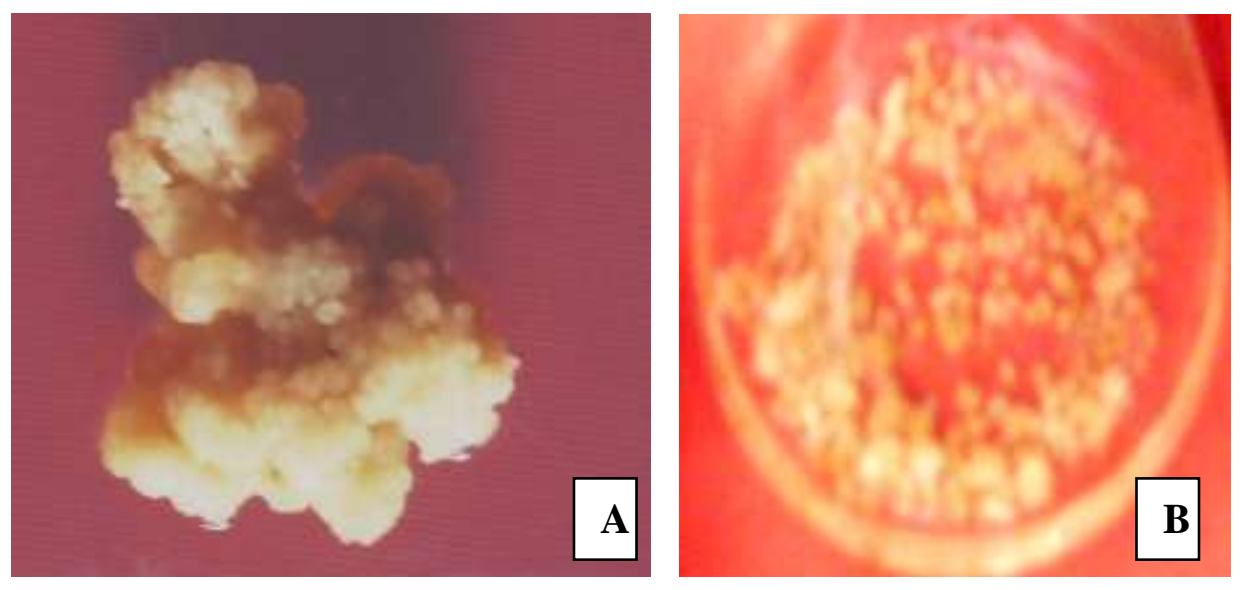

FIGURE 2 CONTINUE PAGE 100 

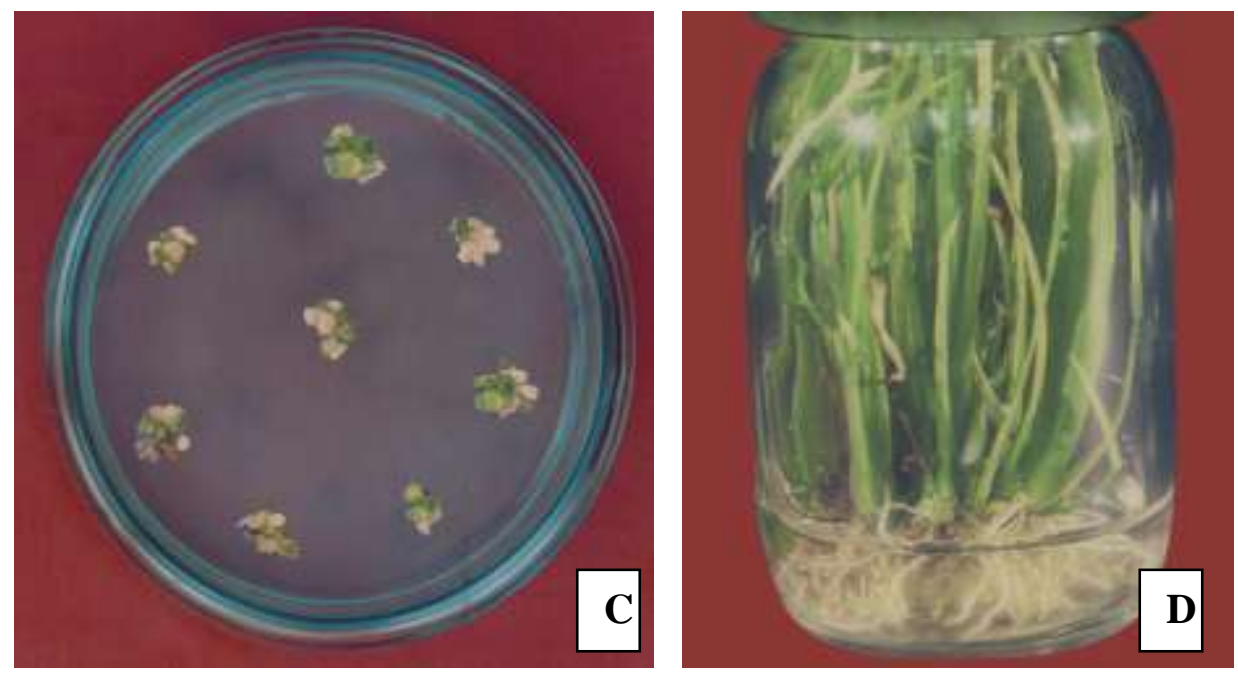

FIG. 2 (A-D): THE DIFFERENT IN VITRO STAGES OF RICE CELL SUSPENSION CULTURES AND PLANT REGENERATION: (A) WELL DEVELOPED EMBRYOGENIC CALLI INDUCED FROM MSS ON MS BASED MEDIUM IN VARIETY HAJA-1, (B) EMBRYOGENIC CELL SUSPENSIONS (21/2 MONTHS-OLD) IN R2 MEDIUM, (C) SHOOT REGENERATED FROM SUSPENSION-DERIVED CELL PRE-TREATED WITH WATER FOR $5 \mathrm{H}$ AND CULTURED ON MSBP REGENERATION MEDIUM, (D) SUSPENSION CELLS-DERIVED PLANTS WITH STRONG ROOT.

Rapidly growing fine textured plant cell cultures can provide a homogenous cell population for many studies in plant biology. The present study demonstrated the establishment of reproducible systems for embryogenic cell suspension cultures of two deepwater rice varieties, variety HAJA-1 and HAJA-8, together with the efficient plant regeneration. Additionally several factors, besides genotype, were found to influence cell suspension growth such as the amount of viable biomass/culture medium employed, culture vessel size, subculture regime and gaseous exchange (Schmitz and Lorz 1990a, b; Khaleda and Al-Forkan 2006). In general, rice as well as with plant species, genotype has been considered to be an important factor affecting the potential for regeneration in vitro (Owaza and Komamine 1989). This study clearly supports this view (Table 2, 3 and 4). However, this study also demonstrated that plant regeneration frequencies could be improved by treatment such as manipulation of regeneration medium with growth regulators (Table 2), partial-desiccation with high agarose concentration (Table 3) and pre-treatment of cell suspension with water (Table 4). 


\section{PLANT REGENERATION FROM EMBRYOGENIC CELL SUSPENSION CULTURE OF RICE}

It has been reported that a $50 \%$ of reduction of water content (by $24 \mathrm{~h}$ dehydration treatment) in rice callus (cv. Sasanishiki) increased the regeneration frequency by $49 \%$ (Tsukahara and Hirosawa 1992). In a recent study, the stimulatory effect of partial-desiccation increased plant regeneration from seed scutellar derived calli of three Indica rice cvs. (Rance et al. 1994). Similarly, partial-desiccation also increased plant regeneration from cell-suspension derived calli of three Indica rice cvs. (Jain et al. 1996b).

Variety HAJA-1 showed the best response, including fast growth rates of callus and cells. For cell cycle analysis, it is critical that cell culture displays a fine texture and rapid growth under homogenous environmental conditions. Two major problems in developing and maintaining a suitable rice cell culture system, as reported by Thompson et al. (1986) and it is similar in this study, are a slow rate of cell growth and formation of large cell clumps during the cell culture period. In the present study, partial desiccation [using 1\% (w/v) agarose] also increased plant regeneration frequencies directly from cell suspensions (initiated in R2 medium) of the variety HAJA-1 and HAJA-8. Furthermore, plant regeneration frequencies were also increased, from cell suspensions of both the variety HAJA-1 and HAJA-8 only, when the cells were pre-treated with water (5 h) and cultured on MSBP medium. These results suggested that there existed the possibility of the presence of some unknown substance(s), which inhibited plant regeneration and were secreted into the culture medium, and therefore washing the cells for 1-5 $\mathrm{h}$ was effective for removing the inhibitor(s).

However washing the cell suspensions with water for a prolonged period of time (15 h and more), inhibited plant regeneration (Table 4). Therefore, increased plant regeneration frequencies cannot be attributed to any osmoticum effects. This system could be employed to produce large scale of plant from small quantity of mature embryos seeds as starting materials. Embryogenic suspension culture can be established by continuously culturing the calli in a liquid medium

for continuous source of experimental material. It seems that the present study shows a simple method to enhance regeneration frequency from suspension cells, which can be used for genetic transformation studies.

\section{REFERENCES}

ABE, T. AND FUTSUHARA, Y. 1991. Diallel analysis of callus growth and plant regeneration in rice seed callus. Japan J. Genet. 66: 129-140. 
AL-FORKAN, M., ANTHONY, P., POWER, J. B., DAVEY, M. R. AND LOWE, K. C. 2001. Haemoglobin (Erythogen ${ }^{\text {Tm}}$ ) enhanced microcallus formation from protoplasts of Indica rice (Oryza sativa L.). Art. Cells Blood Subs. and Immob. Biotechnol. 29(5): 399-404.

BLACKHALL, N. W., JOTHAM, J. P., AZHAKANANDAM, K. POWER, J. B., LOWE, K. C., COCKING, E. C. AND DAVEY, M. R. 1999. Callus initiation maintenance and shoot induction in rice In: Methods in Molecular Biology. Hall E (Ed.), Humana Press Inc. Totowa, N J pp. 19-29.

GHOSH BISWAS, G. C. AND ZAPATA, F. J. 1992. Plant regeneration from long-term cell suspension cultures of Indica rice (Oryza sativa L. cv. IR43). J. Plant Physiol. 139: 523-527.

JAIN, R. K., JAIN, S. AND WU, R. 1996. Stimulatory effect of water stress on plant regeneration in aeromatic Indica rice varieties. Plant Cell Rep. 15: 449-454.

KHALEDA, L. AND AL-FORKAN, M. 2006. Stimulatory effects on casein Hydrolysate and proline in in vitro callus induction and plant regeneration from five deepwater rice (Oryza sativa L.). Biotechnol. 5(3): 379-384.

LEE, S .Y., KIN, H. S. AND KWON, T. O. 2004. Variation in anther culture response and fertility of back crossed hybrids between Indica and Japonica rice (Oryza sativa L.). Plant Cell Tiss. and Org. Cult. 79: 25-30.

LINSMAIER, E. M. AND SKOOG, F. 1965. Organic growth factor requirements of tobacco tissue cultures. Physiol. Plant. 18: 100-127.

MURASHIGE, T. AND SKOOG, F. 1962. A revised medium for rapid growth and bioassays with tobacco tissue cultures. Physiol. Plant. 15: 431497.

OHIRA, K., OJIMA, K. AND FUJIWARA, A. 1973. Studies on the nutrition of rice cell culture I. A simple defined medium for rapid growth in suspension culture. Plant Cell Physiol. 14: 1013-1121.

OZAWA, K. AND KOMAMINE, A. 1989. Establishment of a system of highfrequency embryogenesis from long-term cell suspension cultures of rice (Oryza sativa L.) Theor. Appl. Genet. 77: 205-211.

RANCE, I. M., TIAN, W., MATHEWS, H., DE KOCHKO, A., BEACHY, R. N. AND FAUQUET, C. 1994. Partial desiccation of mature embryoderived calli, a simple treatment that dramatically enhances the regeneration ability of Indica Rice. Plant Cell Rep. 13: 647-651. 
SCHMITZ, U. AND LORZ, H. 1990a. Nutrient uptake in suspension cultures of Gramineae I. Development of an assay system. Plant Sci. 66: 87-94.

SCHMITZ. U. AND LORZ, H. 1990b. Nutrient uptake in suspension cultures of Gramineae II. Suspension culture of rice (Oryza sativa L). Plant Sci. 66: $95-111$.

TANG, K., SUN, X., AN, D., POWER, J. B., COCKING, E. C. AND DAVEY, M. R. 2001. A simple and rapid procedure to establish embryogenic cell suspension as a source of protoplasts for efficient plant regeneration from two Chinese commercial rice cultivars. Plant Cell Tiss. Org. Cult. 66(2): 149-153.

THOMPSOM, J. A., ABDULLAH, R. AND COCKING, E. C. 1986. Protoplasts culture of rice (Oryza sativa L.) using media solidified with agarose. Plant Sci. 47: 123-133.

TSUKAHARA, M. AND HIROSAWA, T. 1992. Simple dehydration treatment promotes regeneration of rice (Oryza sativa L.) callus. Plant Cell Rep. 11: 550-553.

TSUKAHARA, M., HIROSAWA, T. AND HISHINE, S. 1996. Efficient plant regeneration from calli suspension cultures of rice (Oryza sativa L.). J. Plant Psysiol. 149:157-162.

WENGING, T., BAO, L. AND MIAO, X. 1997. Establishing japonica rice suspension retaining a high regeneration potential after 14 months of culture. Plant Cell Tiss. Org. Cult. 47: 213-216.

ZHU, Y., QUYANG, W., LI, Y. AND CHEN, Z. 1996. The effect of Zip and 2, 4-D on rice calli differentiation. Plant Growth Reg. 19: 19-24.

Manuscript received on 12. 2. 2011; Accepted on 29.9.11

The Chittagong University Journal of Biological Sciences, Vol. 5 (1 \& 2). Page No: 91-103 